\title{
APPLICATION OF FUZZY AGGREGATION NORMS IN VOCATIONAL GUIDANCE FOR LAW GRADUATES
}

\author{
Aleksandra Mreła, Oleksandr Sokolov \\ Nicolaus Copernicus University Grudziadzka Torun, Poland
}

\begin{abstract}
Higher education institutions want to help their graduates to find a job, which is more relevant to their personal traits. The law graduates can apply for a job for a great variety of positions. Some of them require dealing with clients every day, like for example an attorney, and the others demand preparing legal documents individually. Graduates also differ due to willingness and capacity of working with people or preparing documents alone. The paper presents the mathematical model of an information system designed for analyzing the graduates traits and different job requirements to help the law graduates choose the kind of job to apply to it. The model is based on fuzzy aggregations norms.
\end{abstract}

Key words: decision support system, higher education, fuzzy aggregation norms.

\section{Introduction}

When students graduate from universities, they want to find a job or run a business within the framework of their achieved qualifications. The graduates of law have a great variety of positions to apply. Because of that, the higher educational institutions should help them to choose for which kinds of jobs they are better qualified. Some graduates work during their studies, so they have some knowledge about their abilities, and they can choose their future job with more probability of success, but some students cannot gain some experience during their university studies, so they have a problem to decide which kind of job they are better qualified for. In Poland, it is more important in law than in many other areas of professional higher education because to apply for some position like for example judge, attorney, notary and so on, the law graduates have to complete more studies, called law applications [1]. In the case of an attorney, the graduates have to study three years more, so the cost of making a mistake is high.

\section{Fuzzy relations}

When people want to describe somebody's traits, they use some phrases like "they must manage the stressful situation very well", "they cannot leave everything for the last moment" and so on. The application of classical logic for this situation is not convenient, because it is a very rare situation when there is a person who possesses the considered trait completely or does not possess it at all. Much more often, people possess the discussed trait at some level. Because of that, it is much better to use fuzzy logic which is multi-valued. Fuzzy logic enables to model the level of truth sentences like for example "The attorneys should like to work with people very much, work well under the pressure of time and do not need to be good at preparing regulations or bills."

Lofti Zadeh [2] introduced the idea fuzzy sets. Let $\mathrm{X}$ be a non-empty space and let $\mathrm{A} \subseteq \mathrm{X}$. Then, $A$ is called a fuzzy set if $A=\left\{\left(\mathrm{x}, \mu_{A}\right), \mathrm{x} \in\right.$ $\mathrm{X}\}$ and $\mu_{A}: X \rightarrow[0,1]$ is a membership function. For each $\mathrm{x} \in \mathrm{X}$, value $\mu_{A}(x)$ describes the level of membership of this element to set A. Assume that $\mathrm{X}$ and $\mathrm{Y}$ are two spaces. Then, $\mathrm{R} \subseteq \mathrm{X} \times \mathrm{Y}$ is called a fuzzy relation between $\mathrm{X}$ and $Y$ if $R$ is a fuzzy set.

Let $X$ be a set of some positions for law graduates $(X$ does not include all possible positions for law graduates). Let

$$
X=\{A T, L C, P A t, A U, B R, J U, P A r, L S, P O, B A, N O, L C, I L\},
$$

where $A T$ denotes an attorney, $L C$ - a legal counsel, $P A-$ a patent attorney, $A U$ - an auditor, $B R-$ a bankruptcy receiver, $J U-$ a judge, $P A-$ a public prosecutor, $L S$ - a legal secretary, $P O$ - a probation officer/curator, $B A-\mathrm{a}$ bailiff,
$N O$ - a notary, $L C$ - a legal clerk and $I L-$ an inhouse lawyer.

Moreover, let $Y$ be a set of some traits which the different law professionals should possess in different levels, 


$$
Y=\left\{Y_{1}, Y_{2}, Y_{3}, Y_{4}, Y_{5}, Y_{6}\right\},
$$

where $Y_{1}$ denotes the ability to work with people, $Y_{2}$ - to work alone (at home, in the office or library), $Y_{3}$ - to manage the stressful situations, $Y_{4}$ - to be conscientious, timely and disciplined, $Y_{5}$ - to act spontaneously and the trait of leaving

things for the last moment, $Y_{6}$ - the necessity to earn money after the graduation.

Let $R \subseteq X \times Y$ be a fuzzy relation between positions for the law graduates and required traits, where $R\left(A T, Y_{1}\right)=0.3$ denotes that, for attorneys, the ability work with people is relatively high.

Assume that values of relation $R$ fulfill the following condition

$$
\sum_{j=1}^{6} R\left(X_{i}, Y_{j}\right)=1 \quad \text { for each } j=1,2, \ldots, 6 \text {. }
$$

Tab. 1 - Values of the fuzzy relation between law professionals and required traits

\begin{tabular}{|c|c|c|c|c|c|c|c|}
\hline \multicolumn{2}{|c|}{$\begin{array}{c}\text { Trait } \\
\text { Position }\end{array}$} & $Y_{1}$ & $Y_{2}$ & $Y_{3}$ & $Y_{4}$ & $Y_{5}$ & $Y_{6}$ \\
\hline$A T$ & $X_{1}$ & 0.2 & 0.3 & 0.2 & 0.2 & 0.1 & 0 \\
\hline$L C$ & $X_{2}$ & 0.2 & 0.2 & 0.1 & 0.2 & 0.2 & 0.1 \\
\hline$P A t$ & $X_{3}$ & 0.3 & 0.1 & 0.1 & 0.1 & 0.2 & 0.2 \\
\hline$A U$ & $X_{4}$ & 0.1 & 0.5 & 0.1 & 0.1 & 0.1 & 0.1 \\
\hline$B R$ & $X_{5}$ & 0.1 & 0.3 & 0.2 & 0 & 0.1 & 0.3 \\
\hline$J U$ & $X_{6}$ & 0.2 & 0.3 & 0.2 & 0.2 & 0.1 & 0 \\
\hline$P A r$ & $X_{7}$ & 0.2 & 0.1 & 0.1 & 0.2 & 0.2 & 0.2 \\
\hline$L S$ & $X_{8}$ & 0 & 0.2 & 0.3 & 0.1 & 0.2 & 0.2 \\
\hline$P O$ & $X_{9}$ & 0.1 & 0.4 & 0.1 & 0.2 & 0.1 & 0.1 \\
\hline$B A$ & $X_{10}$ & 0.4 & 0.2 & 0.2 & 0 & 0.1 & 0.1 \\
\hline$N O$ & $X_{11}$ & 0.2 & 0.1 & 0.1 & 0.1 & 0.3 & 0.2 \\
\hline$L C$ & $X_{12}$ & 0.2 & 0 & 0.3 & 0.2 & 0.2 & 0.1 \\
\hline$I L$ & $X_{13}$ & 0.1 & 0.3 & 0.2 & 0.3 & 0.1 & 0 \\
\hline
\end{tabular}

Let $Z=\left\{G_{1}, G_{2}, G_{3}, G_{4}, G_{5}\right\}$ be the set of law graduates who need the help to choose the profession and let $V: \subseteq Y \times Z$ be a fuzzy relation between the professional traits and graduates.
Values of relation $V$ can be evaluated by a specialist-psychologist or by the graduates themselves. The exemplary values are presented in table 2 .

Tab. 2 - Values of the fuzzy relation between required traits and graduates based on the self-assessment or established by a psychologist

\begin{tabular}{|c|c|c|c|c|c|}
\hline $\begin{array}{c}\text { Graduates } \\
\text { Traits }\end{array}$ & $G_{1}$ & $G_{2}$ & $G_{3}$ & $G_{4}$ & $G_{5}$ \\
\hline$Y_{1}$ & 0.3 & 0.5 & 0.7 & 0.2 & 0.9 \\
\hline$Y_{2}$ & 0.7 & 0.7 & 0.9 & 0.6 & 0.1 \\
\hline$Y_{3}$ & 0.4 & 0.8 & 0.4 & 0.7 & 0.5 \\
\hline$Y_{4}$ & 0.3 & 0.4 & 0.5 & 0.9 & 0.2 \\
\hline$Y_{5}$ & 0.5 & 0.2 & 0.7 & 0.3 & 0.5 \\
\hline$Y_{6}$ & 1 & 0 & 0.8 & 0.5 & 0.7 \\
\hline
\end{tabular}

\section{The function of trust in professional traits}

The article deals with the problem of trusting in the graduate's professional traits in the area of law professional positions.

Let $\mathrm{T}: \mathrm{X} \times Z \rightarrow[0,1]$ be a function, called the trust-in-professional-traits function (the trust function). Let us consider for the law graduate $G_{0} \in Z$ and one of the professions - attorney AT $\in X:$

- $\mathrm{T}\left(G_{0}, \mathrm{AT}\right)=1$, then the trust that graduate $G_{0}$ possesses the set of traits required for being an attorney in the perfect level, then this graduate can be recommended for this profession;

- $\mathrm{T}\left(G_{0}, \mathrm{AT}\right) \in(0,1)$, then the trust is positive and the bigger this number is, the higher the trust that the traits of this graduate are proper for this position;

- $\mathrm{T}\left(G_{0}, \mathrm{AT}\right)=0$, then this graduate should choose another law position because the traits are really on a very low level. 


\section{Fuzzy aggregation norms}

Now, we are going to introduce fuzzy aggregation norms.

\section{Optimistic fuzzy aggregation norms}

The optimistic fuzzy aggregation norm [3] is defined based on by three conditions (O1)-(O3). By (O3), it may be observed that the level of value after the application of the optimistic fuzzy aggregation norm is not less than each value chosen for calculations.

Let $S_{o}:[0,1] \times[0,1] \rightarrow[0,1]$ be an optimistic fuzzy aggregation norm if the following conditions are fulfilled, let $x, y \in[0,1]$ :

$$
\begin{aligned}
& S_{o}(0,0)=0 \\
& S_{o}(\mathrm{x}, \mathrm{y})=S_{o}(\mathrm{y}, \mathrm{x}) \\
& S_{o}(\mathrm{x}, \mathrm{y}) \geq \max \{\mathrm{x}, \mathrm{y}\}
\end{aligned}
$$

Condition (O1) shows that if the considered value is 0 and the next value added is also 0 , then the level of the norm is 0 . Condition (O2), named commutativity, says that the order of adding information is not important. Condition (O3) shows that after the use of optimistic fuzzy aggregation norm is bigger or equal than values taken into calculations.

Let the following function be chosen as an optimistic aggregation norm. Let $\mathrm{x}, \mathrm{y} \in[0,1]$,

$$
S_{o}(\mathrm{x}, \mathrm{y})=\mathrm{x}+\mathrm{y}-\mathrm{xy} .
$$

Figure 1 shows the graph of the optimistic fuzzy aggregation norm.

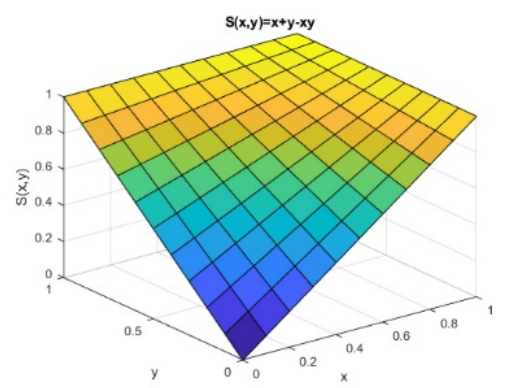

Fig. 1. The graph of optimistic fuzzy relation aggregation norm $S_{o}$

\section{T-norm of fuzzy relations}

For calculation results of the composition of two fuzzy relations, the $t$-norm [4] will be applied. The function $t:[0,1] \times[0,1] \rightarrow[0,1]$ is called $t$ norm if the following conditions are fulfilled for each $x, y, z, v \in[0,1]$

(t1) $t(x, y) \leq t(z, v)$ for $x \leq z, y \leq v$

(t2) $t(x, y)=t(y, x)$ (t3) $t(t(x, y), z)=t(x, t(y, z))$

(t4) $t(x, 1)=x$

Condition (t1) shows that the function $t$ is monotonous. Condition (t2), called commutativity, shows that the order of two calculated values is not important. Condition ( $\mathrm{t} 3$ ), called associativity, shows that it does not matter whether at first $t$-norm of values $x$ and $y$ are calculated and then $t$-norm of the result with $z$ is calculated, or the order of calculations is different. Condition (t4) shows that $t$-norm of each value with 1 is always this value.

Let, for the $t$-norm, the following function

$$
t(\mathrm{x}, \mathrm{y})=\mathrm{xy}
$$

for each $x, y \in[0,1]$, will be applied.

Figure 2 presents the graph of the t-norm.

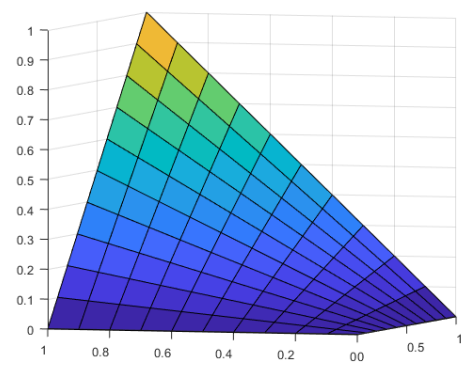

Fig. 2. The graph of t-norm

\section{Model of the trust-in-professional-traits}

At first the following fuzzy relation

$W\left(G_{i}, Y_{j}, X_{k}\right)$, for $i=1,2, \ldots, 5, j=1,2, \ldots, 6$

and $k=1,2, \ldots, 13$,

be defined as follows $W\left(G_{i}, Y_{j}, X_{k}\right)=$ $t\left(V\left(G_{i}, Y_{j}\right), R\left(Y_{j}, X_{k}\right)\right)=V\left(G_{i}, Y_{j}\right) \cdot R\left(Y_{j}, X_{k}\right)$.

(*)The trust-in-professional-traits function is defined as follows

$$
\begin{gathered}
T_{1}\left(G_{i}, X_{k}\right)=W\left(G_{i}, Y_{1}, X_{k}\right) \\
T_{j+1}\left(G_{i}, X_{k}\right)=S_{o}\left(T_{j}\left(G_{i}, X_{k}\right), W\left(G_{i}, Y_{j}, X_{k}\right)\right) \\
\text { for } j=1,2, \ldots, 5 \\
T\left(G_{i}, X_{k}\right)=T_{6}\left(G_{i}, X_{k}\right) .
\end{gathered}
$$

for each $i=1,2, \ldots, 5$ and $k=1,2, \ldots, 13$.

Let us calculate, as an example, the level of trust-in-professional-traits for the graduate $G_{1}$ considering the application for position $X_{1}$. At the beginning, values of relation $W\left(G_{1}, Y_{j}, X_{1}\right)$ for all values $j=1,2, \ldots, 6$, are calculated and presented in table 3.

Based on the values of relation $W$, values of $T\left(G_{i}, X_{k}\right)$ and sums of values of fuzzy relation $W$ are presented in table 4 . 
Tab. 3 - Values of the fuzzy relation $W$ for graduate $G_{1}$ applying for the position $X_{1}$

\begin{tabular}{|l|c|c|c|c|c|c|}
\hline Traits & $Y_{1}$ & $Y_{2}$ & $Y_{3}$ & $Y_{4}$ & $Y_{5}$ & $Y_{6}$ \\
\hline$W\left(G_{1}, Y_{j}, X_{1}\right)$ & 0.06 & 0.21 & 0.08 & 0.06 & 0.05 & 0 \\
\hline
\end{tabular}

Tab. 4 - Levels of trust-in-professional-traits for graduates and professional law positions and sums of values of fuzzy relation $W$

\begin{tabular}{|c|c|c|c|c|c|c|c|c|c|c|c|}
\hline \multicolumn{2}{|c|}{$\begin{array}{c}\text { Graduate } \\
\text { Position }\end{array}$} & \multicolumn{2}{|c|}{$G_{1}$} & \multicolumn{2}{c|}{$G_{2}$} & \multicolumn{2}{|c|}{$G_{3}$} & \multicolumn{2}{|c|}{$G_{4}$} & \multicolumn{2}{c|}{$G_{5}$} \\
\cline { 2 - 14 } & $\sum W$ & $\mathrm{~T}$ & $\sum W$ & $\mathrm{~T}$ & $\sum W$ & $\mathrm{~T}$ & $\sum W$ & $\mathrm{~T}$ & $\sum W$ & $\mathrm{~T}$ \\
\hline$A T$ & $X_{1}$ & 0,46 & 0,3899 & 0,57 & 0,4615 & 0,66 & 0,5166 & 0,57 & 0,4615 & 0,40 & 0,3471 \\
\hline$L C$ & $X_{2}$ & 0,50 & 0,4091 & 0,44 & 0,3711 & 0,68 & 0,5179 & 0,52 & 0,4247 & 0,46 & 0,3866 \\
\hline$P A t$ & $X_{3}$ & 0,53 & 0,4326 & 0,38 & 0,3298 & 0,69 & 0,5264 & 0,44 & 0,3674 & 0,59 & 0,4792 \\
\hline$A U$ & $X_{4}$ & 0,60 & 0,4980 & 0,54 & 0,4655 & 0,76 & 0,6009 & 0,56 & 0,4650 & 0,33 & 0,2889 \\
\hline$B R$ & $X_{5}$ & 0,67 & 0,5312 & 0,44 & 0,3822 & 0,73 & 0,5585 & 0,52 & 0,4302 & 0,48 & 0,4038 \\
\hline$J U$ & $X_{6}$ & 0,46 & 0,3899 & 0,57 & 0,4615 & 0,66 & 0,5166 & 0,57 & 0,4615 & 0,40 & 0,3471 \\
\hline$P A r$ & $X_{7}$ & 0,53 & 0,4320 & 0,37 & 0,3199 & 0,67 & 0,5115 & 0,51 & 0,4178 & 0,52 & 0,4270 \\
\hline$L S$ & $X_{8}$ & 0,59 & 0,4715 & 0,46 & 0,3976 & 0,65 & 0,5048 & 0,58 & 0,4648 & 0,43 & 0,3682 \\
\hline$P O$ & $X_{9}$ & 0,56 & 0,4611 & 0,51 & 0,4326 & 0,72 & 0,5600 & 0,59 & 0,4766 & 0,34 & 0,2961 \\
\hline$B A$ & $X_{10}$ & 0,49 & 0,4047 & 0,52 & 0,4336 & 0,69 & 0,5353 & 0,42 & 0,3584 & 0,60 & 0,5013 \\
\hline$N O$ & $X_{11}$ & 0,55 & 0,4464 & 0,35 & 0,3051 & 0,69 & 0,5264 & 0,45 & 0,3745 & 0,55 & 0,4475 \\
\hline$L C$ & $X_{12}$ & 0,44 & 0,3702 & 0,46 & 0,3959 & 0,58 & 0,4611 & 0,54 & 0,4447 & 0,54 & 0,4399 \\
\hline$I L$ & $X_{13}$ & 0,46 & 0,3905 & 0,56 & 0,4563 & 0,64 & 0,5063 & 0,64 & 0,5106 & 0,33 & 0,2906 \\
\hline
\end{tabular}

The sum $\sum W$ can be used to calculate levels of trust-in-professional-traits, but there are two disadvantages:

1) The sum might be bigger than 1 .

2) The sum might not have enough different values to prepare rankings of graduates.

\section{Results}

To estimate whether the graduate should be recommended for the given profession, let us calculate the range $=($ Min, Max $)$. Here, Min $=$ 0.29 and $\operatorname{Max}=0.60$, so the range is $(0.29$; 0.60 ). Let $\mathrm{d}=$ Max-Min $=0.31$.

Assume that if the level of trust-inprofessional-traits $T\left(G_{i}, X_{k}\right)$ is lower than Min + $30 \% \mathrm{~d}=0.383$, then the graduate $G_{i}$ should not apply for position $X_{k}$; if the level of trust-inprofessional-traits $T\left(G_{i}, X_{k}\right)$ belongs to interval $(\operatorname{Min}+30 \% d, \operatorname{Max}-30 \% d)=$

$(0.383,0.507)$, then the graduate can apply for this position, but they are advised to think about the position better for them; if finally the level of trust-in-professional-traits $T\left(G_{i}, X_{k}\right)$ is higher than Max $-30 \% d=0.507$, then the graduate is recommended for this position.

Moreover, the rankings of students can be prepared to recommend. Let us prepare the ranking for the position of attorney. Comparing values of $\mathrm{T}$ from table 4 , it can be noticed that the best graduate is $G_{3}(0.5166)$, then $G_{2}$ and $G_{4}$
(0.4615), next $G_{1}(0.3899)$ and the last one is $G_{5}$ (0.3471).

\section{Bibliography}

1. A. Nowak-Gruca, Aplikacja, budżetówka, korporacja czy uczelnia?, Mentor: Prawo,

https://dopierwszejpracy.pl/aleksandra-nowakgruca/aplikacja-budzetowka-korporacja-czyuczelnia, [11.03.2018].

2. Paprocki M., Co dalej po studiach prawniczych? Tendencyjnie, edukacjaprawnicza.pl, 2013,

http://www.edukacjaprawnicza.pl/co-dalej-postudiach-prawniczych-tendencyjnie/, [11.03.2018].

3. Perendyk R., Od czego zacząć, aby zrobić karierę w zawodzie prawnika..., JobFitter, 2018, http://www.jobfitter.pl/kariera/od-czego-zaczacaby-zrobic-kariere-w-zawodzie-prawnika, [11.03.2018].

4. Rutkowski L., Metody i techniki sztucznej inteligencji, PWN, Warszawa, 2012.

5. Sokolov O., Osińska W., Mreła A., Duch W., Modeling of Scientific Publications Disciplinary Collocation Based on Optimistic Fuzzy Aggregation Norms, Advances in Intelligent Systems and Computing, Volume 853 Information Systems Architecture and Technology: Proceedings of 39th International Conference on Information Systems Architecture and Technology - ISAT 2018 Part II, ISBN 978-3-319-99995-1, pp 145156, (C) Springer Nature Switzerland AG 2019. 
6. Wang, X., Ruan, D., Kerre E.E., Mathematics of Fuzziness - Basic Issues. Springer-Verlag Berlin Heidelberg, 2009.

7. Zadeh L., Fuzzy sets, Information and Control, vol. 8,1965 , pp. 338-353

\section{ЗАСТОСУВАННЯ НЕЧІТКИХ АГРЕГАЦЙНИХ СТАНДАРТІВ ПРОФЕСІЙНОЇ ОРІЄНТАЦІЇ ВИПУСКНИКІВ ЮРИДИЧНИХ ВИЩИХ НАВЧАЛЬНИХ ЗАКЛАДІВ}

Анотація. Вищчі навчальні заклади прагнуть допомогти своїм випускникам знайти роботу, яка більше відповідає їхнім особистим рисам. Випускники права можуть подати заявку на роботу на безліч різних посад. Деякі з них вимагають спілкування з клієнтами щзодня, як, наприклад, адвокат, а інші вимагають підготовки юридичних документів індивідуально. Випускники також відрізняються за бажанням та спроможністю працювати з людьми або самостійно готувати документи. Коли треба описати особливість особи, часто використовують такі фрази, як "особа повинна добре управляти стресовою ситуацією", "не може залишити все в останню мить" тощо. Застосування класичної логіки для цієї ситуації не є зручним, оскільки ие дуже рідкісна ситуація, коли є людина, яка повністю володіє розглянутою ознакою або взагалі не володіє нею. Набагато частіме люди мають обговорювану рису на певному рівні. Через ие набагато краме використовувати нечітку логіку, яка $\epsilon$ багатозначною. Нечіткі логіки дозволяють моделювати рівень істинних речень, таких як, наприклад, «Адвокати дуже люблять праџювати 3 людьми, добре праџювати під тиском часу $i$ не повинні бути належними при підготовці правил або векселів». В роботі подано математичну модель інформаційної системи, призначену для аналізу ознак випускників та різних вимог до роботи, з тим щуоб допомогти випускникам юриди- чних наук вибирати вид роботи, до якої звертатися. Модель побудована на базі нечітких агрегачійних норм.

Ключові слова: система підтримки прийняття рішень, вища освіта, норми нечіткої агреzauiii.

\section{ПРИМЕНЕНИЕ НЕЧЕТКИХ \\ АГРЕГАЦИОННЫХ СТАНДАРТОВ ПРИ ПРОФЕССИОНАЛЬНОЙ ОРИЕНТАЦИИ ВЫПУСКНИКОВ ЮРИДИЧЕСКИХ ВЫСШИХ УЧЕБНЫХ ЗАВЕДЕНИЙ}

Аннотация. В работе представлена математическая модель информационной системы, предназначенной для анализа признаков выпускников и различных требований к работе, с тем чтобы помочь выпускникам юридических специальностей выбирать вид работы. Применение классической логики для этой ситуации не является удобным, поскольку это очень редкая ситуация, когда есть человек, который полностью владеет рассматриваемой проблемой или вообще не владеет ею. Модель построена на базе нечетких агрегационных норм.

Ключевые слова: система поддержки принятия решений, высшее образование, нормы нечеткой агрегации

Prof. dr hab. inż. Oleksandr Sokolov

Department of Informatics Faculty of Physics, Astronomy and Informatics

Nicolaus Copernicus University Grudziadzka 5

87-100 Torun, Poland

osokolov@fizyka.umk.pl

Dr Aleksandra Mrela

Faculty of Technology Kujawy and Pomorze University in Bydgoszcz

55-57, Toruńska85-023 Bydgoszcz, Poland

a.mrela@kpsw.edu.pl 